\title{
Three new species of the subfamily Coelotinae (Araneae: Amaurobiidae) from Kyushu, Japan
}

\author{
Ken-ichi Okumura \\ Nagasaki Prefectural Hirado Senior High School, Kusazumi-cho 261, Hirado-shi, Nagasaki, 859-5392, Japan \\ E-mail: coelotes@ybb.ne.jp
}

\begin{abstract}
Three new species of the subfamily Coelotinae are described from Kyushu, Japan, under the names, Coelotes gotoensis n. sp., Coelotes iharai $\mathrm{n}$. sp. and Iwogumoa nagasakiensis $\mathrm{n}$. $\mathrm{sp}$. Coelotes gotoensis is a large and dark-colored coelotine spider, which has two retromarginal teeth on chelicera, and is characterized by having large and digitiform patellar apophysis on male palp. This new species has only been found in Narushima Is., Goto Islands, Nagasaki Pref. Coelotes iharai is characterized by having palpal conductor roundish in male and epigynal teeth sharp by pointed in female. This new species lives in Mts. Kirishima and the surrounding areas between Miyazaki and Kagoshima Pref. and the entire region of Kumamoto Pref. Iwogumoa nagasakiensis has a characteristic spatula-shaped conductor in male palp. This new species is distributed in Goto Islands, Hirado Is., Ikitsuki Is., Azuchi-oshima Is., and in the western part of the mainland of Nagasaki Pref.
\end{abstract}

Key words - Araneae, Coelotes, Iwogumoa, new species, Kyushu, Japan

\section{Introduction}

Spiders of the subfamily Coelotinae are widely distributed in Japan and show a large diversity of species. Systematic studies on this group in Kyushu are fewer than those in other districts in Japan (Okumura \& Ono 2006). Therefore I have surveyed in Kyushu for several years, and collected three undescribed species from Nagasaki, Kumamoto, Miyazaki and Kagoshima Pref. In this paper, I will describe them under the names, Coelotes gotoensis, $C$. iharai and Iwogumoa nagasakiensis, respectively.

The genus Coelotes, consisting of over forty species in Japan, is the main group in Japanese coelotine spiders (Platnick, 2006). A great variety of size, color, genital organ and number of teeth of chelicera is recognized in this group, therefore, taxonomical studies on this group are insufficient (Wang, 2002). Coelotes gotoensis n.sp. seems to belong to the same group of Coelotes unicatus Yaginuma 1977, and C. bifurcatus Okumura \& Ono 2006, by having large-sized body, dark coloration, and having two retromarginal teeth of chelicera. Coelots iharai n. sp. is similar to C. tarumii Arita 1976, by having small-sized body and four retoromarginal teeth of chelicera.

The genus Iwogumoa was proposed by Kishida in 1955, but unfortunately this name was treated as a nomen nudum (Brignoli 1983, Platnick 2006) because Kishida's paper was written in Japanese and therefore foreign researchers took no notice of this name, while Japanese arachnologists, who almost always treated coelotine species under the single genus Coelotes, also neglected the name of Iwogumoa. However, Nishikawa \& Ono (2004) regarded this name as available and as a senior synonym of Asiacoelotes Wang 2002. I agree with this treatment and use Iwogumoa as a valid name in this paper. Nishikawa \& Ono (2004) also stated that four Japanese species which were assigned to Asiacoelotes by Wang (2002) belong to Iwogumoa, but they only showed Japanese names of the species; the four species are as follows: Iwogumoa acco (Nishikawa 1987), I. insidiosa (L. Koch 1878), I. interuna (Nishikawa 1977) and I. yaeyamensis (Shimojana 1982). The main characteristics of this genus are having long and slender embolus and elongated cymbial furrow in male palp, and short epigynal teeth situated anteriorly on epigynum (Wang, 2002). Features of Iwogumoa nagasakiensis $\mathrm{n}$. $\mathrm{sp}$. completely conform with these characteristics.

The abbreviations used in this paper are as follows: ALE, anterior lateral eye; AME, anterior median eye; MOA, median ocular area; PLE, posterior lateral eye; PME, posterior median eye.

The type specimens of the new species described in this paper will be deposited in the collection of the Department of Zoology, National Museum of Nature and Science, Tokyo.

I wish to express my sincere thanks to Dr. Hirotsugu Ono, Tokyo for reading the manuscript and for helpful suggestions. My heartfelt thanks are also due to Mr. Yoh Ihara, Hiroshima, for providing the specimens used in this study. 
Coelotes gotoensis n. sp.

(Japanese name: Goto-yachigumo)

Figs. 1-4, 13

Types. All the type specimens were collected from Narushima Is., Goto Islands, Nagasaki Pref., Kyushu, Japan, and by K. Okumura. Holotype: $\delta^{\top}$, Kumataka, February 6 , 2005 (NSMT-Ar 6816). Allotype: 우, same locality as the holotype, February 28, 2004 (NSMT-Ar 6817). Paratypes:

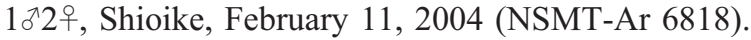

Description. Male holotype. Measurements in $\mathrm{mm}$. Total length 10.7; carapace 5.4 long, 3.5 wide; abdomen 5.3 long, 3.7 wide; sternum 2.9 long, 2.1 wide. Eye sizes: AME 0.13, ALE 0.22, PME 0.18, PLE 0.20. Distances between eyes: AME-AME 0.10, AME-ALE 0.08, PME-PME 0.13, PME-PLE 0.20, AME-PME 0.20, ALE-PLE 0.07. MOA: anterior width 0.36 , posterior width 0.49 , length 0.51 . Leg measurements as shown in Table 1.
Chericeral retromargin with two teeth.

Male palp (Figs. 1-2): embolus short and arciform, conductor short and stout, median apophysis large and slightly swirled, patellar apophysis robust and digitiform, retrorateral tibial apophysis flat, lateral tibial apophysis quite small.

Coloration: carapace brown with gray radial flecks, dorsum of abdomen grayish brown with yellowish brown irregular flecks, sternum reddish brown, chelicerae, maxillae and labium reddish black, legs brown with gray ring flecks on femur, patella and tibia.

Female allotype. Measurements in $\mathrm{mm}$. Total length 12.1; carapace 5.3 long, 3.5 wide; abdomen 6.8 long, 5.0 wide; sternum 2.7 long, 2.1 wide. Eye sizes: AME 0.13, ALE 0.23, PME 0.20, PLE 0.20. Distances between eyes: AME-AME 0.12, AME-ALE 0.10, PME-PME 0.17, PMEPLE 0.25, AME-PME 0.25, ALE-PLE 0.07. MOA: anterior width 0.38 , posterior width 0.57 , length 0.58 . Leg measurements as shown in Table 1.

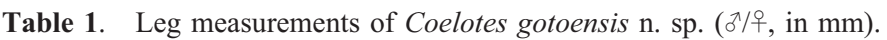

\begin{tabular}{cccccc}
\hline Legs & Femur & Patella and Tibia & Metatarsus & Tarsus & Total \\
\hline I & $4.14 / 3.87$ & $5.40 / 4.54$ & $4.14 / 3.13$ & $2.60 / 1.93$ & $16.28 / 13.47$ \\
II & $4.00 / 3.47$ & $4.80 / 4.07$ & $3.74 / 3.07$ & $2.33 / 1.73$ & $14.87 / 12.34$ \\
III & $3.74 / 3.27$ & $4.27 / 3.87$ & $3.94 / 3.07$ & $1.80 / 1.67$ & $13.75 / 11.88$ \\
IV & $4.94 / 4.00$ & $5.60 / 5.00$ & $5.27 / 4.27$ & $2.27 / 2.00$ & $18.08 / 15.27$ \\
\hline
\end{tabular}
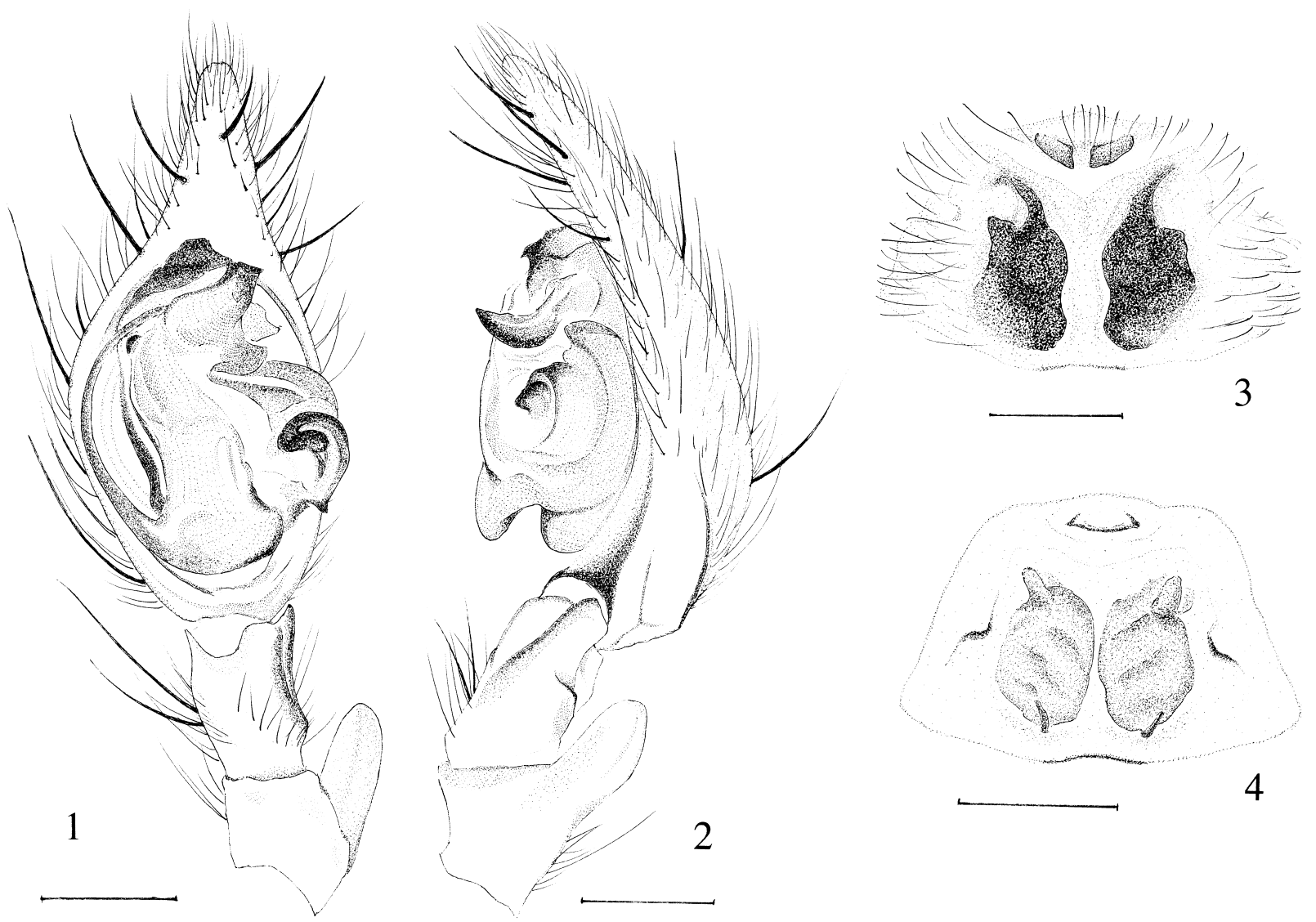

Figs. 1-4. Coelotes gotoensis n. sp. - 1, Male palp, ventral view; 2, same, retrolateral view; 3, epigynum; 4, internal female genitalia. Scales: $0.5 \mathrm{~mm}$. 
Chericeral retromargin with two teeth.

Epigynum and internal genitalia (Figs. 3-4): epigynal plate trapeziform; epigynal teeth small, closely to each other, and situated anteriorly on epigynal plate; posterior part around copulatoly openings widely blackly pigmented; spermathecae large and closely to each other.

Coloration of the female allotype almost same as that of the male holotype.

Other specimens examined. All the specimens were collected from Narushima Is., Goto Islands, Nagasaki Pref., Kyushu, Japan, and by K. Okumura. Funamawari: 1우, September 20, 2003; Kumataka: 4우 February 28, 2004; 3주 9우, March 13, 2004; 3저2우, December 11, 2004; 3저우, February 6, 2005.

Distribution. Narushima Is., Goto Islands, Nagasaki Pref., Japan.

Etymology. Specific name is derived from the type locality.

Remarks. This species resembles Coelotes unicatus Yaginuma 1977 and C. bifurcatus Okumura \& Ono 2006 in large and dark external features, and its two teeth on cheliceral retromargin, but can be clearly distinguished from them by the structure of genital organs of both sexes. One of the distinctive characteristics of this new species is having the robust and digitiform patellar apophysis in male palp.
Coelotes iharai n. sp.

(Japanese name: Minami-hime-yachigumo)

Figs. 5-8, 13

Types. All the type specimens were collected from Kyushu, Japan, and by K. Okumura. Holotype: ${ }^{\top}$, Kirishima-higashi-zinja, $510 \mathrm{~m}$ alt., Takaharu, Miyazaki Pref., October 14, 2006 (NSMT-Ar 6819). Allotype: 우, Mt. Kurino, $740 \mathrm{~m}$ alt., Kagoshima Pref., October 12, 2006 (NSMT-Ar 6820). Paratypes: 1ऽ1우, same data as the allotype (NSMT-Ar 6821).

Description. Male holotype: Measurements in $\mathrm{mm}$. Total length 5.1; carapace 2.7 long, 1.7 wide; abdomen 2.4 long, 1.4 wide; sternum 1.4 long, 1.2 wide. Eye sizes: AME 0.09, ALE 0.15, PME 0.13, PLE 0.13. Distances between eyes: AME-AME 0.03, AME-ALE 0.03, PME-PME 0.05, PME-PLE 0.09, AME-PME 0.10, ALE-PLE 0.03. MOA: anterior width 0.21 , posterior width 0.31 , length 0.32 . Leg measurements as shown in Table 2.

Chericeral retromargin with four teeth.

Male palp (Figs. 5-6): embolus short; conductor short, arciform and roundish in the tip; median apophysis scrolled to inside; patellar apophysis short and slightly twist; retrorateral tibial apophysis somewhat projecting; lateral tibial apophysis reduced.

Coloration: carapace grayish brown with gray radial flecks, around of ocular area black, dorsum of abdomen dark gray with yellowish brown chevrons, sternum grayish brown, chelicerae, maxillae and labium reddish brown, legs
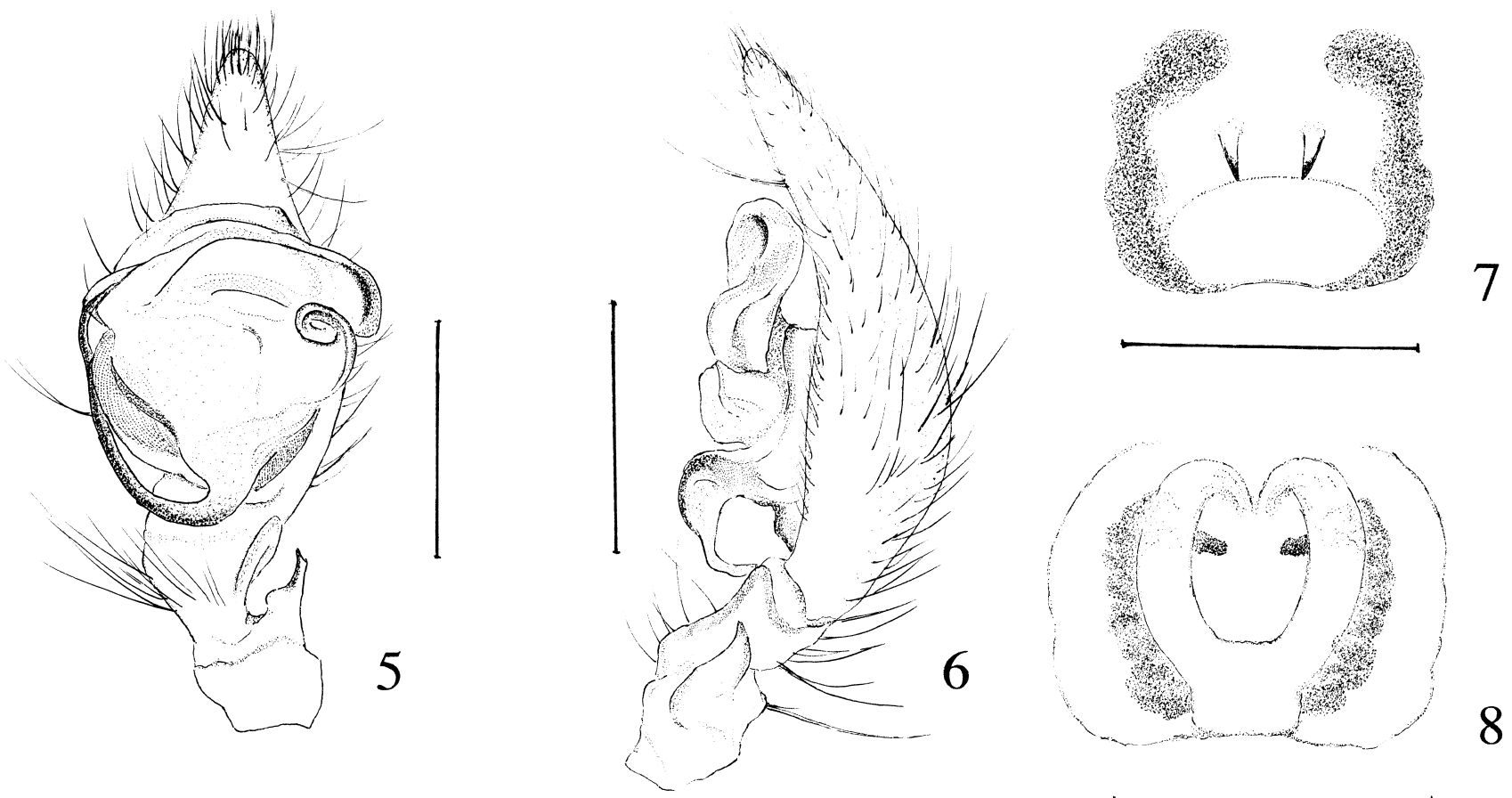

Figs. 5-8. Coelotes iharai n. sp. - 5, Male palp, ventral view; 6, same, retrolateral view; 7, epigynum; 8, internal female genitalia. Scales: $0.5 \mathrm{~mm}$. 
grayish brown with gray flecks on femur, patella and tibia.

Female allotype: Measurements in $\mathrm{mm}$. Total length 5.2; carapace 2.7 long, 1.6 wide; abdomen 2.5 long, 1.6 wide; sternum 1.4 long, 1.2 wide. Eye sizes: AME 0.08, ALE 0.13, PME 0.13, PLE 0.13. Distances between eyes: AMEAME 0.04, AME-ALE 0.05, PME-PME 0.08, PME-PLE 0.10, AME-PME 0.11, ALE-PLE 0.05. MOA: anterior width 0.19 , posterior width 0.33 , length 0.32 . Leg measurements as shown in Table 2.

Chericeral retromargin with four teeth.

Epigynum and internal genitalia (Figs. 7-8): epigynal plate square-shaped with lateral edges darkish; epigynal teeth small, situated in center of epigynum; long spermathecae along U-shaped copulatory ducts.

Coloration of the female allotype almost same as that of the male holotype.

Other specimens examined. All the specimens were collected from Kumamoto Pref, Kyushu, Japan, and by Y. Ihara. Kikuchi-keikoku: 1ठ3우, October 8, 1975; Mt. Kitamuki, Ozu-machi, Kikuchi-gun: 1우, September 20,
1981; 1우, September 23, 1992; Mt. Ichifusa, Kuma-gun: 1우 October 27, 1985; Fukamizu, Sakamoto-mura, Yatsushirogun: 1ð22우, October 13, 2001.

Distribution. Kagoshima, Kumamoto and Miyazaki Pref., Japan.

Etymology. Specific name is dedicated to Mr. Yoh Ihara for the first discovery of this new species.

Remarks. This species resembles Coelotes tarumii Arita 1976 by its small-sized body and four retoromarginal teeth of chelicera, but can be clearly distinguished from the latter by the following points. Conductor of male palp of $C$. tarumii is elongated, but that of $C$. iharai $\mathrm{n}$. sp. is not elongated and roundish. Epiginal teeth of $C$. tarumii are not pointed, but those of $C$. iharai $\mathrm{n}$. sp. are sharp. Copulatory ducts of $C$. tarumii are partly hidden by long spermatheca, but those of $C$. iharai n. sp., presented large and U-shaped are quite recognized.
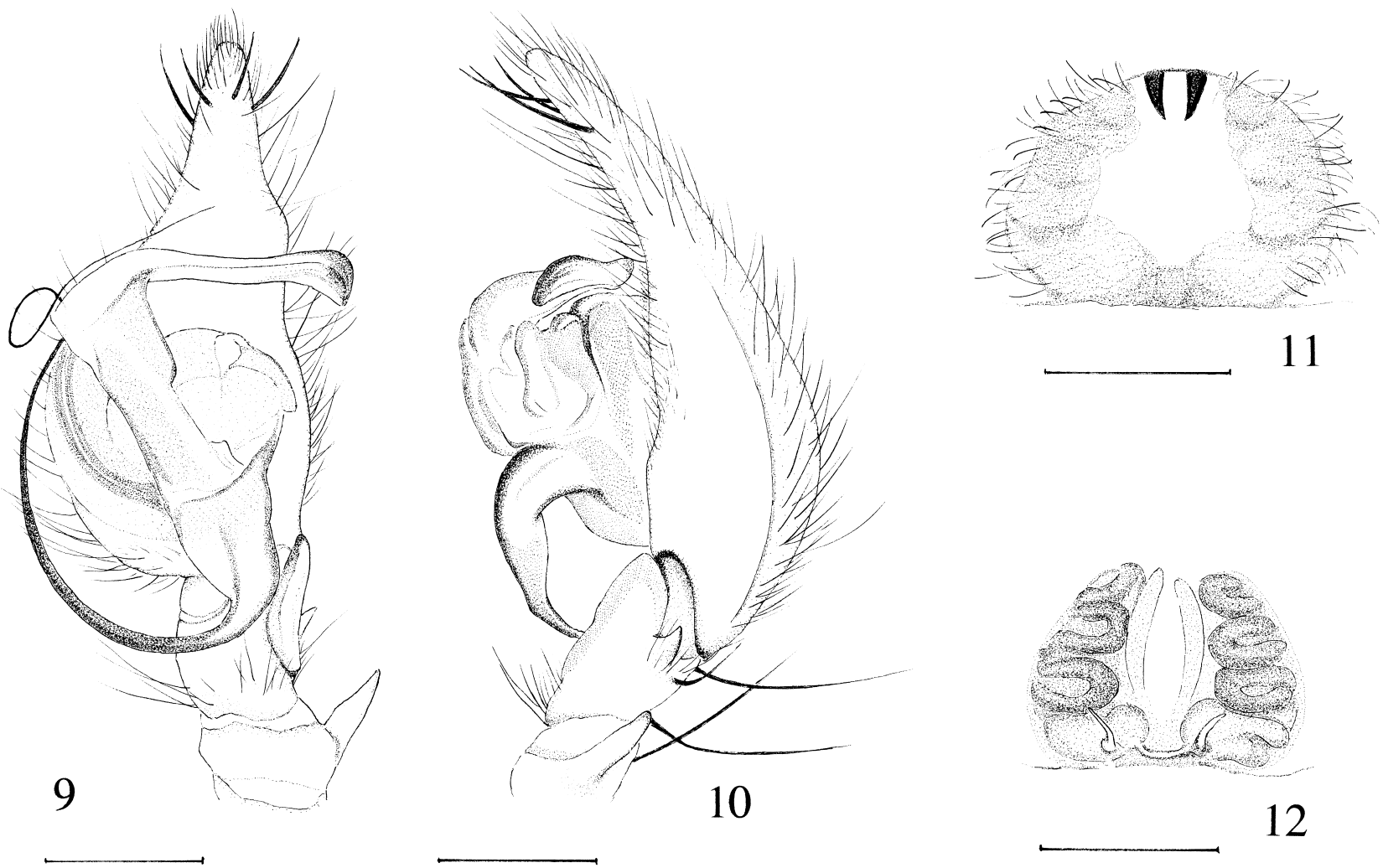

Figs. 9-12. Iwogumoa nagasakiensis n. sp. - 9, Male palp, ventral view; 10, same, retrolateral view; 11, epigynum; 12, internal female genitalia. Scales: $0.5 \mathrm{~mm}$.

Table 2. Leg measurements of Coelotes iharai n. sp. ( $3 /$ / 9 , in mm).

\begin{tabular}{cccccc}
\hline Legs & Femur & Patella and Tibia & Metatarsus & Tarsus & Total \\
\hline I & $1.84 / 1.80$ & $2.44 / 2.24$ & $1.76 / 1.48$ & $1.08 / 0.92$ & $7.12 / 6.44$ \\
II & $1.84 / 1.68$ & $2.12 / 1.76$ & $1.72 / 1.32$ & $0.92 / 0.84$ & $6.60 / 5.60$ \\
III & $1.68 / 1.56$ & $1.92 / 1.76$ & $1.68 / 1.32$ & $0.80 / 0.68$ & $6.08 / 5.32$ \\
IV & $2.24 / 2.04$ & $2.64 / 2.44$ & $2.36 / 2.04$ & $1.04 / 0.88$ & $8.28 / 7.40$ \\
\hline
\end{tabular}




\section{Iwogumoa nagasakiensis $\mathrm{n}$. $\mathrm{sp}$}

(Japanese name: Nagasaki-shimofuri-yachigumo)

Figs. 9-13

Types. All the type specimens were collected from Nagasaki Pref., Kyushu, Japan, and by K. Okumura. Holotype: ${ }^{\curvearrowright}$, Mt. Yasuman-dake, $500 \mathrm{~m}$ alt., Hirado Is., November 13, 2005 (NSMT-Ar 6822). Allotype: 우, same data as the holotype (NSMT-Ar 6823). Paratypes: 236우, Miiraku-cho, Fukue Is., Goto Islands (NSMT-Ar 6824-
$6825)$.

Description. Male holotype. Measurements in $\mathrm{mm}$. Total length 6.4; carapace 3.3 long, 2.4 wide; abdomen 3.1 long, 1.9 wide; sternum 1.6 long, 1.4 wide. Eye sizes: AME 0.17, ALE 0.17, PME 0.17, PLE 0.14. Distances between eyes: AME-AME 0.04, AME-ALE 0.03, PME-PME 0.09, PME-PLE 0.11, AME-PME 0.10, ALE-PLE 0.03. MOA: anterior width 0.39 , posterior width 0.43 , length 0.44 . Leg measurements as shown in Table 3.

Cheliceral retromargin with three teeth.

Male palp (Figs. 9-10): embolus extremely long and

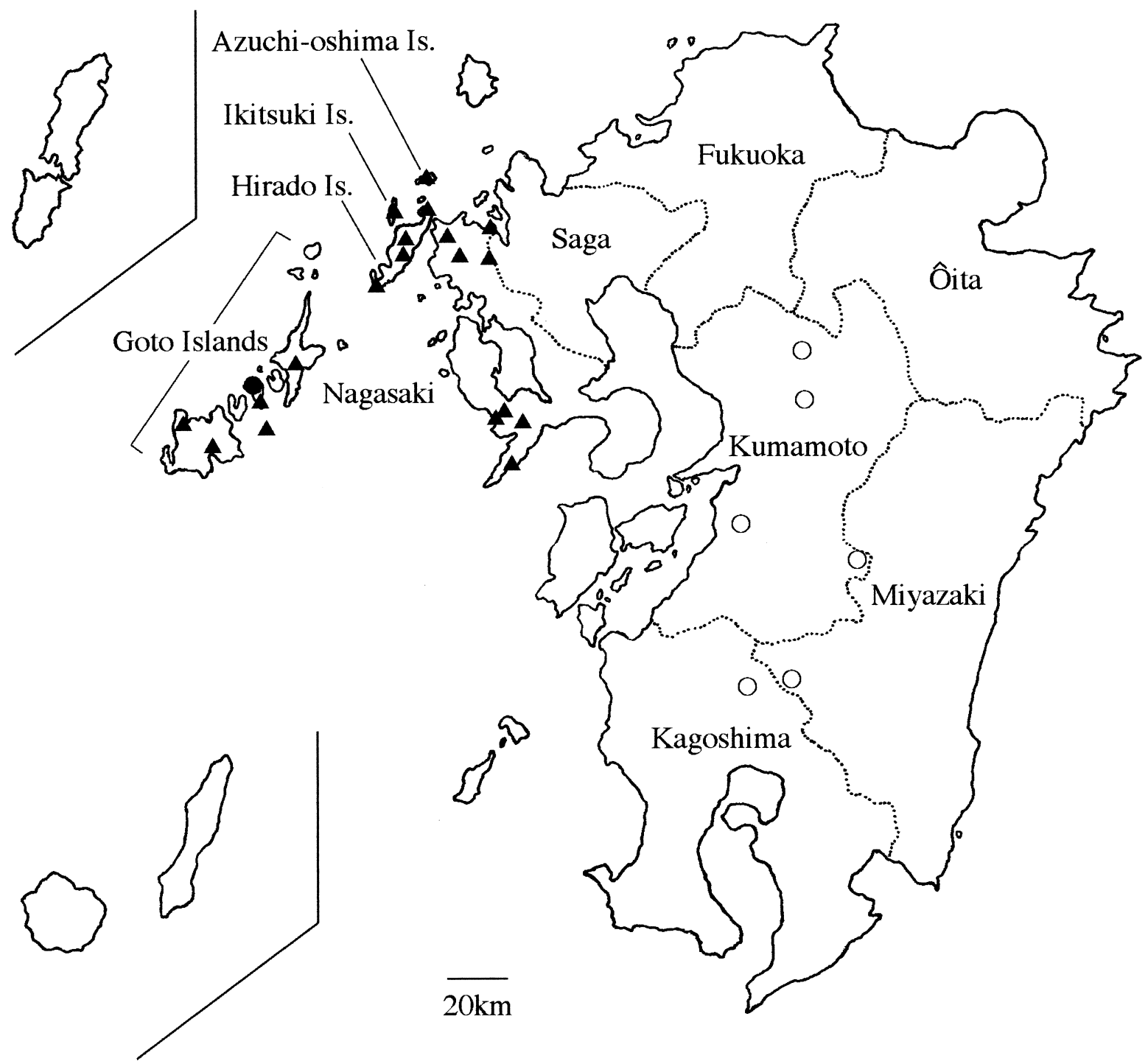

Fig. 13. Distribution of Coelotes gotoensis n. sp., Coelotes iharai n. sp. and Iwogumoa nagasakiensis n. sp. in the Kyushu district, Japan. : Coelotes gotoensis; $\bigcirc$ : Coelotes iharai; $\mathbf{\Delta}$ : Iwogumoa nagasakiensis.

Table 3. Leg measurements of Iwogumoa nagasakiensis n. sp. ( $\varsigma^{1} / \%$, in $\mathrm{mm}$ ).

\begin{tabular}{cccccc}
\hline Legs & Femur & Patella and Tibia & Metatarsus & Tarsus & Total \\
\hline I & $2.87 / 2.77$ & $3.86 / 3.62$ & $2.72 / 2.38$ & $1.54 / 1.44$ & $10.99 / 10.21$ \\
II & $2.62 / 2.53$ & $3.32 / 3.12$ & $2.38 / 2.23$ & $1.39 / 1.24$ & $9.71 / 9.12$ \\
III & $2.43 / 2.38$ & $2.92 / 2.83$ & $2.50 / 2.28$ & $1.14 / 1.04$ & $8.99 / 8.53$ \\
IV & $3.27 / 3.17$ & $3.86 / 3.86$ & $3.61 / 3.17$ & $1.44 / 1.24$ & $12.18 / 11.44$ \\
\hline
\end{tabular}


slender, conductor spatula-shaped and not pointed, cymbial furrow elongated, median apophysis of tegrum reduced, patellar apophysis hornlike, retrolateral tibial apophysis broad and flat, lateral tibial apophysis small.

Coloration: carapace yellowish brown with gray radial flecks, dorsum of abdomen grayish brown with yellowish brown chevrons, sternum yellowish brown, chelicerae, maxillae and labium reddish brown, legs yellowish brown with gray ring flecks on femur, patella and tibia.

Female allotype. Measurements in $\mathrm{mm}$. Total length 7.9; carapace 3.6 long, 2.5 wide; abdomen 4.3 long, 3.1 wide; sternum 1.9 long, 1.6 wide. Eye sizes: AME 0.17, ALE 0.17, PME 0.17, PLE 0.17. Distances between eyes: AME-AME 0.05, AME-ALE 0.03, PME-PME 0.08, PMEPLE 0.15, AME-PME 0.10, ALE-PLE 0.03. MOA: anterior width 0.38 , posterior width 0.42 , length 0.43 . Leg measurements as shown in Table 3.

Cheliceral retromargin with three teeth.

Epigynum and internal genitalia (Figs. 11-12): epigynal teeth short, closely to each other, and situated in anterior portion of epigynal plate; spermathecae long and convoluted; copulatory duct longitudinally elongated.

Coloration of the female allotype almost same as that of the male holotype.

Other specimens examined. All the specimens were collected from Nagasaki Pref, Kyushu, Japan, and by K. Okumura. Narushima Is., Goto Islands: Funamawari: 10 October 27, 2003; Egami: 20, February 14, 2004; Kumataka: 1ㅇ, March 13, 2004; Shioike: 1ðㄱ, December 23,

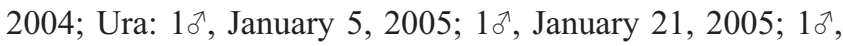
March 17, 2005. Fukue Is., Goto Islands: Kishuku-cho: 3 우, February 5, 2005; Tomie-cho: 54우, March 6, 2005. Kabashima Is., Goto Islands: Kubinoura: $10^{\lambda} 3$ 우, February 27, 2005; Takenoura: 2우, February 27, 2005; Ifukuki: 1주우, February 27, 2005. Nakadori Is., Goto Islands: Shirauo pass: 2 우, February 10, 2006. Hirado Is.: Iwanoue: 1 우, April 17, 2005; 10, November 30, 2005; Neshiko: 1우, April 20, 2005; $1 \mathrm{\delta}^{\top} 2$ 우, April 18, 2006; Mt. Shiro-take: $10^{\top} 1$ 우, October 23, 2005; 2우, November 3, 2005; Kyosaki: 1고우, November 5, 2005; $20{ }^{7} 22$ 우, January 22, 2006; Mt. Jigendake: $1 \delta^{7} 4$ 우, November 9, 2005; Mt. Yasuman-dake: 7 ${ }^{`} 10$ 우, November 13, 2005; $10^{7} 7$ 우, January 7, 2006; $2{ }^{1} 5$ 우, April 23, 2006; 1주우, December 2, 2006; Kawachi pass: 6구웅, November 28, 2005; 1ㅈ1우, February 25, 2006; Noyashiki: 6구우, February 4, 2006; Tanoura: 7우, February 5, 2006;

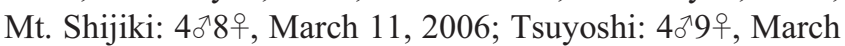
11, 2006; Kusazumi-cho: 1우, April 25, 2006. Hirado-shi: Tabira-cho: 4o'2우, January 28, 2006. Ikitsuki Is.: Yamagashira: $19{ }^{\wedge} 5$ 우, December 24, 2005. Azuchi-oshima
Is.: Hiranotsuji: $40^{7} 7$ 우, December 10, 2005; Itanoura: $17 \delta^{7}$ 11우, December 10, 2005. Matsuura-shi: Toinoura: $7{ }^{\circledR} 13$ 우, November 19, 2005; Shisa-cho: $1{ }^{\top} 1$ 우, October 21, 2006. Nagasaki-shi: Shikimi-cho: 1우 December 18, 2005; Mt. Iwaya: $3 \delta^{7} 2$ 우, February 12, 2006; Mt. Konpira: 2 우 March 4, 2006. Nishisonogi-gun: Kawahara, Sanwa-cho: $10^{\wedge} 3$ 우 October 30, 2005. Sasebo-shi: Yoshii-cho: $11^{\gtrsim} 3$ 우, March 5, 2006; Mt. Kunimi-yama: 6우, September 23, 2006.

Distribution. Nagasaki Pref., Kyushu, Japan.

Etymology. Specific name is derived from the type locality.

Remarks. This species resembles Iwogumoa insidiosa (L. Koch 1878) and I. interuna (Nishikawa 1977), but can be distinguished from the latter two species by the structure of conductor of male palp. The conductor of this new species is spatula-shaped, while that of Iwogumoa insidiosa is a spear-shaped and acuminate, and that of I. interuna is broad and short.

\section{References}

Arita, T. 1976. Three new Coelotes (Araneae, Agelenidae) from Tottori Prefecture, west Japan. Anno. Zool. Japon, 49: 197-204.

Brignoli, P. M. 1983. A catalogue of the Araneae described between 1940 and 1981. Manchester Univ. Press, 755pp.

Kishida, K. 1955. A synopsis of spider family Agelenidae. Acta Arachnol., 14: 1-13. (In Japanese)

Koch, L. 1878. Japanesische Arachniden und Myriapoden. Verhandungen der k.k. zoologischbotanischen Gesellschaft in Wien, 27: 735-798, pls. 15-16.

Nishikawa, Y. 1977. Three new spiders of the genus Coelotes (Araneae: Agelenidae) from Minoo, Osaka, Japan. Acta Arachnol., 27(special number): 33-44. (In Japanese)

Nishikawa, Y. 1987. A new spider, Coelotes acco (Araneae: Agelenidae) from an abandoned mine of the Boso Peninsula, Central Japan. J. Speleol. Soc. Japan., 12: 24-28.

Nishikawa, Y. \& Ono, H. 2004. On generic ramification in the spiders of Coelotinae. Orthobula's Box, 18: 4-5. (In Japanese)

Okumura, K. \& Ono, H. 2006. Two new species and a new synonymy of the subfamily Coelotinae (Araneae: Amaurobiidae) from Kyushu, Japan. Acta Arachnol., 55: 51-58.

Platnick, N. I. 2006. The world spider catalog, version 7.0. American Museum of Natural History, online at http://research.org/ entomology/spiders/catalog/indexhtml.

Shimojana, M. 1982. A new species of the genus Coelotes (Araneae: Amaurobiidae) from the Yaeyama Islands, Okinawa Prefecture, Japan. Acta Arachnol., 30: 75-82.

Wang, X. P. 2002. A generic-level revision of the spider subfamily Coelotinae (Araneae, Amaurobiidae). Bull. Amer. Mus. Nat. Hist., 269: 1-150.

Yaginuma, T. 1977. Spiders from limestone caves of Akiyoshi-dai Plateau, Yamaguchi Prefecture, Japan (II). Acta Arachnol., 27 (special number): 1-21.

Received April 26, 2007 / Accepted September 23, 2007 